Institutional conditions for effective and legitimate industrial policies: the case of Portugal

WP n. ${ }^{\circ} 2012 / 13$

Ricardo Paes Mamede

Paulo Areosa Feio

2012

DOCUMENTO DE TRABALHO

WORKING PAPER

DINAMIP'CET

CENTRO DE ESTUDOS SOBRE A MUDANCA
SOCIOECONÓMICA E OTERBITÓHIO

ISCTE-IUL

\title{
FCT
}




\title{
DINAMIP'CET
}

\section{Institutional conditions for effective and legitimate industrial policies: the case of Portugal}

\author{
Ricardo Paes Mamede * \\ Paulo Areosa Feio **
}

WP n. ${ }^{0} 2012 / 13$

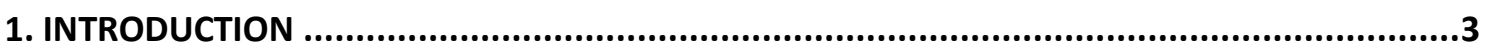

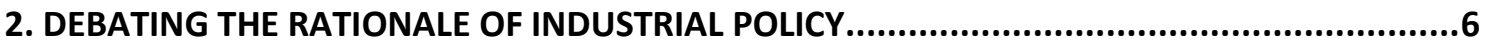

3. HISTORICAL EXPERIENCES OF SUCCESSFUL INDUSTRIAL POLICIES AND THEIR (NON-)

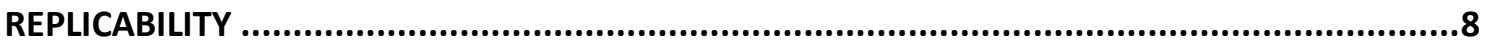

4. OBJECTIVES AND INSTRUMENTS OF INDUSTRIAL POLICY IN PORTUGAL.........................11

4.1. Tax benefits for investment of a contractual nature ........................................................ 12

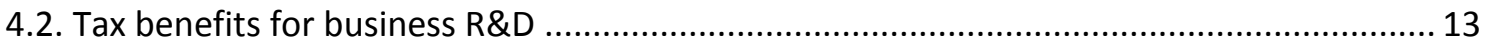

4.3. Direct support for business investment (NSRF incentive schemes) ................................. 14

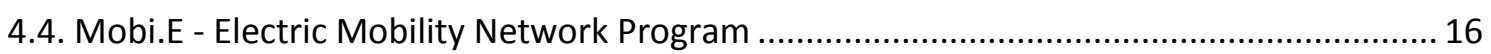

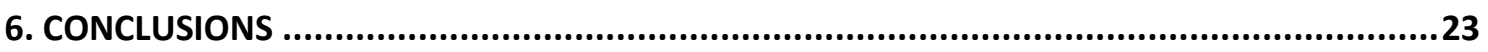

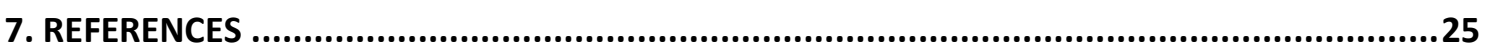

*Department of Political Economy - ISCTE - University Institute of Lisbon, DINÂMIA'CET - IUL, and NSRF Observatory, ricardo.mamede@iscte.pt.

** NSRF Observatory, Centre for Geographical Studies and Institute of Geography and Regional Planning, University of Lisbon, paulo.areosafeio@observatorio.pt. 


\title{
Institutional conditions for effective and legitimate industrial policies: the case of Portugal
}

\begin{abstract}
:
State intervention in support of specific productive activities aiming to foster structural change (i.e., industrial policy) has been a controversial topic in both academic and political debates. In spite of many years of theoretical and empirical research, such debate has not reached definite conclusions. Recently, the debate on industrial policy has been experiencing a change of focus, falling away from the rationale of such public interventions to focus on the institutional conditions that promote the success of the policies pursued.

In this paper we analyse the conditions for effective and legitimate industrial policies, examining four cases of such type of interventions in Portugal. Our analysis emphasises the differences between the various interventions according to two dimensions: the number of (potential) beneficiaries targeted by the policy and the diversity of public agencies in possession of relevant skills for its implementation. These factors help to determine the level of scrutiny to which public policies are subjected, either by private actors or within the State apparatus. Both sources of scrutiny help to minimise the risks of capture of public resources by private interests, and to foster institutional learning processes that promote the effectiveness of policies.
\end{abstract}




\section{INTRODUCTION}

"We have to make some strategic decisions about strategic industries" said Barack Obama, U.S. President, on May $1,2009^{1}$. In the midst of an international economic crisis, the return of industrial policy - i.e., of government policies aimed at specific production activities - was thus decreed, in this case in the form of massive aid from the federal government to the banking sector and the automotive industry. Concurrently, governments in Germany, France, Japan and many other countries announced similar measures, targeted to those and other sectors of activity and presented as essential to long-term economic development of their economies ${ }^{2}$.

The return of industrial policy in the official discourse of governments in the developed world took on the shape of historical discontinuity, after three decades of neoliberal hegemony in the debate on State intervention in the productive fabric. In fact, governments never refrained from intervening to promote conditions conducive to economic growth, far beyond the minimalist exercise of regulatory functions and law enforcement. In most developed countries, the State action invariably extends to areas such as the provision of basic education and general technical training, investment in public infrastructure of transport and communications, or the promotion of scientific research and technological development. Although such interventions are widely accepted as essential to sustained economic growth, they are typically interpreted as being 'horizontal' in nature - i.e., policies that benefit the overall development of economic activities, instead of selected industries. It is this non-discriminating aspect that makes such cross-cutting interventions acceptable even by those who are suspicious of any kind of political interference in the functioning of the price system. In contrast, the government assistance announced by major industrialised countries in response to the 2008/9 crisis are explicitly directed to selected sectors, colliding with the guidelines of the so-called 'Washington Consensus', which characterised the economic policy in most Western countries since the 1980s.

In fact, the recent wave of measures of public support to specific activities have a clear resemblance with the development strategies followed in much of the underdeveloped world in the decades following the Second World War. Such strategies were based on the notion that economic growth is inseparable from an asymmetrical development of the productive sectors, being repeatedly linked to the expansion of higher value added activities, with greater opportunities for productivity growth, addressing the most dynamic segments of demand and where competition in international markets is less intense (Lewis, 1954; Kaldor, 1966; Thirwall, 1979; Pasinetti, 1981). In other words, structural change is not only a consequence but also a cause of economic development. As such, a State committed to promoting sustained economic growth could not fail to take policy initiatives to stimulate the expansion of the most dynamic productive sectors. Or could it?

\footnotetext{
${ }^{1}$ Interview to the C-SPAN broadcast network (http://www.c-span.org/pdf/obamainterview.pdf).

2 The Economist, $12^{\text {th }}$ of August, 2010. 
Recognising that structural change is a key factor in the process of long-term economic development is not the same as accepting that public intervention aimed at promoting this change - i.e., industrial policy - is desirable. The growing dominance of neoliberal doctrine among Western governments has, in fact, questioned the usefulness of industrial policy in promoting economic growth. This doctrine rests on the assumption that the price system is an efficient mechanism for allocating resources and that all obstacles to its full operation should be eliminated. This results in favour of privatisation, removal of State support to specific sectors, as well as the liberalisation of foreign trade and foreign investment, which are the central ingredients of the 'Washington Consensus'. Such liberalising measures, it is argued, lead to a more efficient allocation of resources: provided market signals (i.e., prices) are allowed to accurately reflect the value of goods and services, the argument goes, economic agents take decisions that are of in their best interest and, in doing so, they contribute to economic development.

The debate on industrial policy in the last half century has revolved around the advantages and disadvantages of government intervention, reflecting different judgments about the extent and relevance of so-called 'market failures' and the perverse effects that can result from an attempt to correct any failure through State intervention. After several decades of theoretical and empirical debate, its outcome is not entirely conclusive. ${ }^{3}$

Nevertheless, it is now widely accepted that the public support to the emergence and expansion of the most dynamic economic sectors was a key factor in the success of many of the richest countries (e.g., Chang, 2006), as well as of those instances of successful industrialisation in recent decades (e.g., Wade, 2003). Whilst this argument helps to legitimise industrial policy, its historical nature makes it vulnerable to the non-replicability hypothesis. In fact, the policy instruments that are suitable for a certain level of development may not be in others; political conditions that enabled certain institutional interventions may not occur in all contexts, and the rules and institutions governing international economic relations today are different than they were in the past, altering the space of possibilities for public action.

The debate on industrial policy, therefore, remains open. The difficulty in reaching definite conclusions, however, does not make the debate less relevant. As seen above, the industrial policies are today, as they were in the past, a central element of State intervention in the economy. And the developments that have occurred in the design and implementation of these policies - in terms of priorities, the resources involved, the instruments used, the actors mobilised, or the institutional arrangements - are not indifferent to the discussion about the benefits and risks associated with State intervention in these areas. The careful analysis of the theoretical discussion, combined with a detailed knowledge of specific historical experiences in

\footnotetext{
${ }^{3}$ For opposite conclusions about such debate see Pack-Saggi (2006) and Rodrik (2008a). 
different contexts, constitute valuable contributions to improve the effectiveness and legitimacy of industrial policy.

In fact, the academic and political debate on State intervention in support of specific activities has been shifting focus, moving away from arguing about its rationale, to focus on the political and institutional conditions that favour the effectiveness and legitimacy of policies ${ }^{4}$. In this paper we discuss the necessary conditions to the effectiveness and legitimacy of various industrial policy instruments that have been deployed in Portugal in recent years.

There are two main reasons that make the Portuguese case particularly interesting in the present context.

Firstly, the need to change the profile of productive specialisation is one of the biggest challenges facing the Portuguese economy at present. Lately, economic policy discussions have been almost exclusively centred on the need to correct public finance imbalances, which have been aggravated as a result of the international crisis. However, the sectoral structure of the Portuguese economy and the slow pace of structural change are main ingredients of what is probably the most relevant source of those imbalances - i.e., the low rate of GDP growth since the turn of the century. In fact, the products and sectors in which the country has comparative advantages (using, for example, the Balassa index) largely juxtapose the structure of emerging Asian economies and new EU member states of Eastern Europe (OECD, 2007). After several decades of convergence with the average incomes of OECD countries and the EU, the Portuguese economy now operates with production costs that do not allow it to compete based on price with those emerging economies. Thus, the acceleration of structural change, towards activities with greater growth potential and where international competition is less intense, is now essential to avoid a permanent loss of relative living standards of the Portuguese population.

Secondly, the integration of the Portuguese economy in international institutions like the WTO and the EU entails a set of restrictions on the space of possibilities for public policy that were not present when today's richest countries and many emerging economies developed. Notwithstanding, industrial policy does exist today in Portugal, taking different forms, some of which are not always well understood in their detail and therefore are rarely discussed in terms of their legitimacy and effectiveness.

Such discussion constitutes the core of this text. We begin by briefly reviewing the key terms of the debate on the rationality of industrial policy, discussing some of the most relevant historical experiences, as well as its replicability in the context of a peripheral, developed economy, fully participating in the globalisation and the European integration processes. We then describe the main challenges facing the Portuguese economy in terms of specialisation patterns, as well as a

\footnotetext{
${ }^{4}$ E.g., Rodrik (2008b) and Chang (2010). The discussion promoted by The Economist in July 2010 (http://www.economist.com/debate/overview/177) between Dani Rodrik and Josh Lerner is illustrative of the change of focus of the debate.
} 
set of policy instruments that are in place with the aim of promoting the development of specific activities. Finally, we discuss the institutional conditions for a legitimate and effective industrial policy in the Portuguese case, and how this may differ according to the specificities of each policy instrument.

\section{DEBATING THE RATIONALE OF INDUSTRIAL POLICY}

The defence of industrial policy as fundamental to economic development is based on the notion that private investors are little inclined to make the type of investments that drive structural change. Several factors contribute to explain this ${ }^{5}$. In general, relevant shifts in the productive structure presuppose the development and expansion of activities based on knowledge and skills that are scarce in the prevailing situation. The uncertainty regarding the ability to conduct operations (technical, commercial and institutional) related to fundamentally new activities, as well as the uncertainty regarding the results expected from such investments, are strong disincentives to involvement of private actors in the inception of structural change. Such disincentive is compounded in the case of productive activities that involve huge initial investments, given the difficulty faced by most private investors in mobilising huge financial resources and the tendency of capital markets to channel resources to low risk investments. Such characteristics are typical of some activities which are strategically positioned in the system of inter-industry relations, and which are thus crucial for the development of upstream and downstream sectors, or to mobilise the scientific and technological system for the development effort. In the case of more innovative activities (either technical, commercial or institutional), the uncertainty about the returns to investment is aggravated by appropriability issues: the information (about new products, new processes, new organisational forms, new channels of distribution, new markets, etc..) resulting from those activities may be used by competitors who benefit from the efforts of pioneers without incurring the same costs.

To the above listed arguments in favour of industrial policy, the opponents typically respond with three types of reasons. On the one hand, in line with the defence of the price system as an efficient mechanism for processing information, industrial policy opponents question the relevance of the above mentioned market failures as barriers to development. If there are situations in which the functioning of markets will not enable the most desirable results in social terms, it is argued, such situations are marginal or dealt with through regulatory instruments (for example, the patent system as a stimulus to technological innovation). Moreover, it is considered that the diversity and sophistication of the information necessary to an effective intervention of public authorities in these areas is beyond the powers and capacities of public agencies, and therefore industrial policy will, in most cases, lead to inefficient and ineffective

5 Shapiro (2007) provides an updated and concise survey of this discussion. 
outcomes. Finally, public support to productive activities is seen as particularly prone to capture by vested interests, which influence public policy for their own benefit (Krueger, 1974). Ultimately, the argument goes, the extension of State intervention in the productive sphere only increases the privileges of those elites with the most influential political power, distorting the functioning of market mechanisms with no benefit to the society as a whole.

The theoretical debate between proponents and critics of industrial policy is not settled by empirical research. If, on the one hand, case studies abound illustrating the failure of public interventions in support of specific activities, on the other hand, there are many examples where State support proved crucial to the international success of companies and industries (e.g., Chandra, 2006; Chang, 2006). The use of econometric techniques that try to assess the impacts of public support on the performance of sectors is not conclusive either. Although many of these studies indicate that the effect of industrial policy on the performance of sectors supported is not statistically significant (or is even negative), this kind of analysis faces methodological problems that are difficult to overcome. On the one hand, public support for specific sectors, if well designed, tend to be channelled into activities whose development faces significant hurdles, which justify public intervention. This means that in the short and medium term, it is expected that the performance of these sectors is below the average of the economy (Rodrik, 2008). This methodological difficulty is compounded by the fact that an important part of public support to specific sectors addresses the decline of traditional economic activities, in order to minimise the social costs of structural change - and not to promote this change. Empirical analyses that do not distinguish between two types of interventions tend to underestimate the impact of public support. Additionally, when industrial policy is aimed at activities that are strategically placed in the matrix of inter-industry relations, the goal of the State, rather than enhancing the performance of the sector concerned, may consist in stimulating upstream and downstream activities - and it is at this level that the success of public intervention should be assessed. The statistical measurement of the success of industrial policy still faces a further methodological difficulty, which regards the definition of the most adequate time horizon for assessing the intended impact: many of the interventions, having explicit structural objectives, seek to produce effects in the long-run (often over a decade); however, the longer the period of time between the moment of action and the production of expected results, the more difficult it becomes to distinguish between the effects of specific policies and the impacts of a myriad of other factors (e.g., macroeconomic, technological, political, etc.). Moreover, industrial policy does not always take the form of financial support to enterprises, but may go through interventions that are apparently 'horizontal' (e.g., State laboratories, technology centres, transport and communications infrastructures, vocational training, economic diplomacy), but which often aim to support the development of specific activities. Finally, policies to promote innovative activities are justified, as previously discussed, by the contrast between high levels of 
uncertainty of investment results (which discourages the private interest in the absence of public support) and the benefits for the whole economy arising from its possible success (in the form of new technical and commercial knowledge, and contribution to the structural transformation of economies). However, the high levels of uncertainty involved implies that the probability of success of those projects supported by public policies tends to be smaller than average - but this could be offset by a small proportion of successful projects with high transformation potential. ${ }^{6}$ In sum, neither the confrontation of theoretical arguments nor the outcome of empirical studies allow to definitively resolve the debate about the merit of industrial policies. Nevertheless, examples of contemporary economies that abstain from supporting for specific sectors do not abound. While it is not possible to exclude the presence of other explanatory factors (State capture by special interests, electoral populism, etc.), the widespread diffusion of different forms of industrial policy is at least partly explained by the historical experience of countries that have undergone successful processes of industrialisation.

\section{HISTORICAL EXPERIENCES OF SUCCESSFUL INDUSTRIAL POLICIES AND THEIR (NON-) REPLICABILITY}

Historical research has shown that in virtually all current developed countries the State played a central role in promoting the most dynamic sectors in each period (see Chang, 2006). The rise of England as first industrial power in history has been based, since the late seventeenth century, on a series of measures to promote infant industries, such as: public subsidies to production, distribution of monopoly rights, support for industrial espionage, customs duties, reduced rates for imports of raw materials and the stimulation of primary sector production in the colonies. In the U.S., measures such as protectionist tariffs, prohibition of some imports, production subsidies, bans on the export of key raw materials, import liberalisation, reduced tariffs on intermediate goods, patents and awards for inventions, the setting of standards, the development of transport infrastructure, among others, were an integral part of public policy since the late seventeenth century until after the Second World War. In the same vein, almost all other countries which are today among the richest in the world have resorted to various forms of protectionism and interventionism (public enterprises, economic planning, capital controls, direct and indirect subsidies for export, credit facilities to private companies, close control of foreign investment, support for marketing and $R \& D$, etc.) for promoting economic development.

Likewise, the growth experienced by major Asian economies since the 1960s is inseparable from a number of measures of an interventionist nature, which include: supporting the

\footnotetext{
${ }^{6}$ In this sense, public policies are not dramatically different from the activity of private risk capitalists. 
development of certain sectors (selected by the government, with or without the cooperation of the private sector ) through tariff protection, subsidies and other government support to domestic companies (e.g., information on foreign markets), until they were able to compete internationally; strict control of the banking system by the State; the operation of major public companies, the nationalisation of private companies when they revealed incapable of sound management (typically followed by privatisation, but not always), exchange controls (in order to manage the currency necessary for the import of intermediate goods), the tight control of foreign investment, with high selectivity of the approved investments in order to assure the transfer of know-how to domestic firms; a lax attitude over intellectual property; and public investment in education.

Within the academic debate on these historical experiences (see Wade, 2003), some venture in the hypothesis that the development of the economies concerned occurred in spite of State intervention - and not because of it. The difficulty in sustaining such position lies not only on the wealth of detail on some of the historical analysis of development processes in question (e.g., Amsden, 1989; Wade, 2003; Evans, 1995) - that allow us to understand, on the basis of concrete examples, the central role of the State has played in those experiences - but also from the comparison of those experiences with other countries that followed opposite development strategies. In fact, the most common outcome among several developing countries that followed closely the lines of the 'Washington Consensus' was increasing social inequality and financial instability, along with dismal economic growth (Chang, 2006; Rodrik, 2007).

It is therefore not surprising that many governments now seek to revisit a set of strategies that have borne fruit in the past, refusing to passively accept the results of the operation "natural" market mechanisms. It would be a mistake, however, to try to replicate the policy instruments used in specific spatial and temporal contexts without taking into account the existence of complex interrelationships between different types of instruments, and between these and the political, social and institutional environment in which they were successful in the past.

For example, the various historical analysis of the newly industrialising economies of East Asia (e.g., Amsden, 1989; Wade, 2003; Evans, 1995) converge on the conclusion that the success of the strategies pursued by the State is inseparable from the prevailing internal and international political conditions, a combination of adequate policy objectives and priorities (e.g., monetary stability, promotion of savings, widespread access to education, selective support to production activities), as well as a State apparatus whose operation has proved conducive to the promotion of policy objectives ${ }^{7}$.

However, one should bear in mind that industrial policy faces at present some distinct challenges when compared with those historical experiences. First, the increased international integration in goods and capital markets has changed the conditions under which public policy

\footnotetext{
7 We will come back to this topic below.
} 
is developed. In addition to macroeconomic constraints (e.g., the decreased effectiveness of monetary and exchange rate policies, reduced capacity to manage national savings, increased vulnerability to international financial crises), globalisation has changed the conditions for the viability of partnerships between public and private actors. In a world dominated by relatively closed economies, the interests of private investors largely coincided with the government strategies for economic development; in contrast, the increasing role of multinational corporations and international financial actors in companies around the world decreases the area of overlap of interests (Wade, 2003). For these private actors, the State presents itself today less as a relevant partner than as an obstacle to the development of business strategies - or, worse, as an actor deprived of its bargaining power and hence more vulnerable the extraction of private benefits. For the State, the reduced anchoring of producers to the local economy increases the risk that the support to specific activities will not translate into the development of the domestic economy.

Contemporary globalisation, building on the strengthening of the powers of international institutions (such as the WTO and the EU) in fixing the norms governing international flows of goods and capital, has shrunk the space of possibilities for industrial policy. Policy measures such as imposing constraints on foreign investment (e.g., demanding minimum local contents or the transfer of technology to local producers) or protecting domestic producers against foreign competition are now strongly limited by the WTO. The EU, evoking the principle of 'undistorted competition' within the European common market, requires even stricter limits to the pursuit of policy instruments targeting specific sectors (such as State-owned enterprises, public procurement, or various forms of State aid to businesses). In short, many of the instruments deployed by the State in successful historical experiences of industrial policy are now greatly reduced in scope by international rules and institutions.

Finally, economic development in itself carries along additional difficulties for industrial policy. As per capita income grows, the diversity of goods and services increases and, concurrently, the relevant productive players and the associated power structures multiply. The success of development strategies based on public intervention often leads itself to the emergence of private actors whose power and influence grows with the economy. In this sense, the demands on public authorities in the context of developed countries - both in terms of skills and access to information - are in some sense stricter then in the context of developing economies.

This does not mean, however, that industrial policy has no place in modern States' intervention in the context of developed economies. If the measures recently announced by the governments of the richest countries in the world resonate as a discontinuity in the face of recent decades, this has more to do with the relatively opaque way in which support for specific sectors tends to take place in these countries than with absence of industrial policy measures altogether. The American experience of a discrete and diffuse support for Health and Defence industries (Block, 
2008) - which are the realm of a number of high value-added activities where U.S. dominance persists in the world - is an eloquent example of how policies that are apparently 'horizontal' can be used to serve the development of specific sectors. This is an example that, in one way or another, is repeated in many industrialised countries - such as Portugal.

\section{OBJECTIVES AND INSTRUMENTS OF INDUSTRIAL POLICY IN PORTUGAL}

The Portuguese economy is characterised by a significant proportion of low-technology, low value added, non-tradable and/or non-market activities (CTC QREN, 2010). These features became more intense until the middle of the first decade of this century, as a result of the dynamics of demand and real exchange rate appreciation, encouraging investment in sectors less exposed to international competition.

Among the tradable sectors, a significant proportion of GVA and employment is concentrated in labour intensive activities. These sectors are particularly exposed to two risk factors of a structural nature: on the one hand, they are threatened by a stagnated (or even receding) worldwide demand; moreover, they have to face strong competition from emerging economies, which base their competitiveness on low production costs (including the remuneration of work) (OECD, 2007; IMF, 2008).

Such pattern of specialisation is at the roots of the Portuguese underperformance in international trade and in inflows of foreign direct investment - in contrast to more favourable performance of emerging Asian and Eastern European economies. The resulting decrease in the weight of low-tech industries in the Portuguese economy was compensated by an increasing weight of medium-low-tech industries, while the share of more knowledge-intensive industrial activities remained practically unchanged.

In the years before the international economic crisis that started in 2007-8, Portugal had recorded some positive developments in this field, including the favourable performance of the Technology Balance of Payments (whose annual balance turned positive since 2007, due to the good export performance activities of technical services - engineering, architecture, computer science, among others) as well as the continuing increase in business expenditures in R\&D as a percentage of GDP. Although these dynamics point towards the desired structural transformation of the Portuguese economy, the results in these areas are still modest when compared with the more developed economies. Additionally, the recent evolution of some indicators shows that the process of structural transformation of the Portuguese economy is still fragile. For example, the Technological Balance of Payments decreased in 2008, 2009 and 2010 and the weight of the high-tech and medium high-tech goods in Portuguese exports declined 
during the same period, revealing that the international crisis did not penalise less the more advanced sectors of the Portuguese economy.

In short, the upgrading of its industrial structure is today one of the central challenges facing the Portuguese economy. It is not surprising, therefore, to find in the Portuguese policy landscape a number of instruments and initiatives aiming, more or less explicitly, at promoting the desirable structural change. Next we present four instances of such instruments or projects that help to illustrate this idea - and frame the discussion on the conditions for an effective and legitimate industrial policy.

\subsection{Tax benefits for investment of a contractual nature}

The Statute of Tax Benefits establishes the possibility of granting tax exemptions, reduced rates, tax deductions and other tax benefits to firms, with the aim of enhancing or inhibiting certain behaviours in the public interest. The range of situations under the law is diverse, including: various financial investments, investments in productive capacity, corporate restructuring, among others.

In compliance with the EU competition rules, the Tax Benefits Statute stipulates that "the definition of the objective and subjective conditions for tax benefits must be made in general terms (...) only admitting benefits of an individual nature for exceptional reasons duly justified (...)" (Article 6).

The generic formulation of tax benefits does not prevent, however, that they are actively used by the Portuguese government for the promotion of specific activities. Detailed information on all the tax benefits granted to companies in Portugal was not public until recently and thus a comprehensive analysis of its distribution is not viable. Still, it is possible to carry out this analysis in the case of two forms of tax incentives for investment that have been actively used in Portugal, the first of which regards the investment incentives of a contractual nature.

Tax benefits on a contractual basis are directed to large investment projects (equal to or greater than 5 million Euros), being recurrently used in negotiations with multinational companies interested in installing production capacity in the country, or in domestic investment projects which, for different reasons, are supported by the State. This type of incentive is legally framed by EU rules, and the associated investments must comply with a set of conditions in order to be considered of special national interest. According to the law, such investments must: be relevant to the strategic development of the national economy; contribute to the reduction of regional disparities; induce the creation or maintenance of jobs; and help to enhance technological innovation and the national scientific research efforts. Although these conditions restrict, to a large extent, the scope of activities that may benefit from tax benefits of this type, the industry spectrum of potential beneficiaries is nevertheless broad, including the primary sector, 
manufacturing industries, the tourism-related activities, ICT, R\&D services, and various activities in the areas of environment, energy and telecommunications.

Notwithstanding, the analysis of tax credits granted during the period 1999-2008 shows that these tend to focus on a limited number of industries. Of the approximately 690 million of tax credits approved in the period (corresponding to 118 investment contracts), 96\% were concentrated in manufacturing, more than half of them in just three sectors: pulp and paper, chemical industry and pharmaceutical and electronics industry. Although the support directed to low-tech and medium-low tech industries predominate (in addition to pulp and paper, these include the oil industry, metallurgy and foodstuff), the weight of high-tech and medium hightech industries in the tax credits approved is particularly striking when compared with the relative importance of such sectors in the Portuguese economy. In fact, the more technologyintensive industries account for $4 \%$ of GVA and $1 \%$ of Portuguese companies, but they take in $2 / 5$ of such tax credits.

\section{Sectors that benefit more from investment tax credits contractual in nature (1999-2008)}

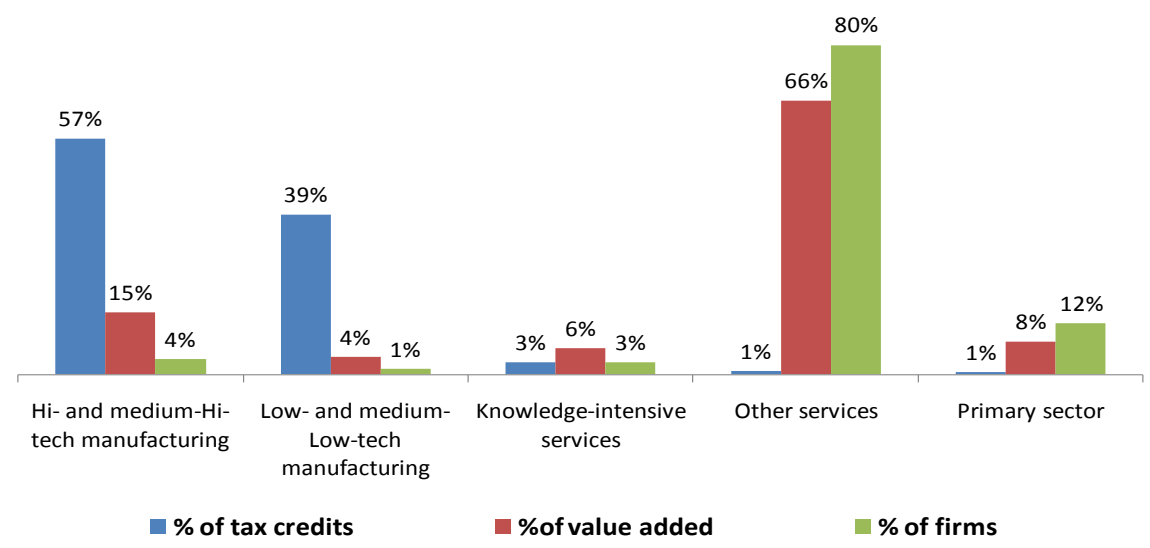

Sources: Tribunal de Contas (2009) and INE.

The intention to foster those industries that do not correspond to the traditional comparative advantages of Portugal is not only visible on the share of electronic industries, chemicals and pharmaceuticals in the tax credits approved for major investment projects. Among the projects supported in this context it is possible to identify recurring investment associated with the automobile and automobile components (e.g., engineering, rubber and plastics), reflecting the priority attached by policy-makers to the promotion of the automotive cluster in Portugal.

\subsection{Tax benefits for business $R \& D$}

The intention of stimulating the development of activities with little weight in the Portuguese productive structure is even clearer in the case of the System of Tax Incentives for Business $\mathrm{R} \& \mathrm{D}$ (SIFIDE). 
Introduced in Portugal in May 1997, the SIFIDE allows for the tax deduction of business expenditures on R\&D (classified according to the OECD Frascati Manual). In a country where business expenditures on R\&D are relatively small and limited to a short number of firms ${ }^{8}$, the impact of instruments like SIFIDE is necessarily selective and asymmetrically distributed across industries. Of the approximately 222 million euro of tax incentives granted under SIFIDE between 2006 and 2008, nearly half were concentrated in six industries, which represent $9 \%$ of GDP and $1 \%$ of domestic companies.

Sectors that benefit most from SIFIDE (2006-2008) and his weight on the economy

\begin{tabular}{|l|c|c|c|c|}
\hline Industry & $\begin{array}{c}\text { Tax credit in } \\
\mathbf{2 0 0 6 / 0 8}(\boldsymbol{\epsilon})\end{array}$ & $\begin{array}{c}\text { \% of total } \\
\text { tax credits }\end{array}$ & $\begin{array}{c}\text { \% of GVA } \\
\text { in 2008 }\end{array}$ & $\begin{array}{c}\text { \% firms in } \\
\mathbf{2 0 0 8}\end{array}$ \\
\hline $\begin{array}{l}\text { Software consultant and related } \\
\text { activities }\end{array}$ & 30.209 .458 & $14 \%$ & $1 \%$ & $1 \%$ \\
\hline $\begin{array}{l}\text { Manufacture of basic } \\
\text { pharmaceutical products and } \\
\text { pharmaceutical preparations }\end{array}$ & 20.775 .113 & $9 \%$ & $0 \%$ & $0 \%$ \\
\hline $\begin{array}{l}\text { Manufacture of motor vehicles, } \\
\text { trailers, semi-trailers and } \\
\text { components for motor vehicles }\end{array}$ & 16.563 .852 & $7 \%$ & $1 \%$ & $0 \%$ \\
\hline Telecommunications & 13.897 .690 & $6 \%$ & $4 \%$ & $0 \%$ \\
\hline $\begin{array}{l}\text { Manufacture of computer, } \\
\text { communications equipment and } \\
\text { electronic and optical products }\end{array}$ & 12.151 .431 & $5 \%$ & $0 \%$ & $0 \%$ \\
\hline $\begin{array}{l}\text { Manufacture of other non-metallic } \\
\text { mineral products }\end{array}$ & 9.980 .104 & $4 \%$ & $2 \%$ & $0 \%$ \\
\hline Total (of the listed industries) & 103.577 .648 & $47 \%$ & $9 \%$ & $1 \%$ \\
\hline
\end{tabular}

Sources: Comissão Certificadora para os Incentivos Fiscais à I\&D Empresarial (2010) and INE.

Some of the industries that benefit the most from SIFIDE were also among the biggest beneficiaries of the tax incentives scheme discussed in the previous section (including pharmaceuticals, automotive and its components, and electronic products). But here we have to highlight the relevance of IT services - which tend to be absent in the case of tax incentives for large investments, due to their strongly immaterial nature - as well as the telecommunications activities (which are traditionally very active in business $R \& D$ in the country). The outstanding support to all these industries is also to be found in other programs and instruments of public policy in Portugal, as the ones discussed below.

\subsection{Direct support for business investment (NSRF incentive schemes)}

In the last two decades, the direct support to firm investment in Portugal was strongly associated with the Cohesion Policy of the EU, which is the main source of finance for such policy

${ }^{8}$ According to official estimates, about 1.800 firms reported R\&D expenditures in 2010. 
instruments. In the first three programming periods of Structural Funds (1988-1993, 1994-1999 and 2000-2006), these direct incentives were relatively little selective in nature, supporting nearly every form of business investment in almost all industries (Augusto Mateus \& Associados , 2005).

Recognising the urgent need for structural change of the Portuguese economy, and reflecting the recommendations resulting from the evaluation of the previous programs, the National Strategic Reference Framework (NSRF) has made a substantial reform of the incentives schemes for business investment co-financed by EU Cohesion Policy in the period 2007-2013. Such reform led, among other things, to a more focused approach, both in terms of number of projects and types of investments. In particular, it was assumed as a priority to support projects related to: business R\&D; product or process innovation; expansion of production capacity in sectors with high technological content or dynamic international demand; knowledge-based entrepreneurship; and the use by SMEs of intangible competitiveness factors (organisation and management, design, products and processes development and engineering, digital economy, fashion and design, internationalisation, and qualification of human resources).

As before, the new incentives schemes allow in principle for supporting investments in almost all productive activities (being conditioned only to the primary activities, construction and financial services). However, its implementation is biased in favour of activities aligned with the goal of structural change. As in the case of tax benefits for investment of a contractual nature, manufacturing is here the main beneficiary, absorbing $2 / 3$ of the roughly 2.3 billion euro of incentives approved (while its weight in terms of VAB is close to $20 \%$ ). More technologyintensive manufacturing industries absorb a proportion of incentives that is five times greater than its weight in the VAB.

Industries that benefit most from the incentive schemes for business investment NSRF (Data from projects approved until June 30, 2010)

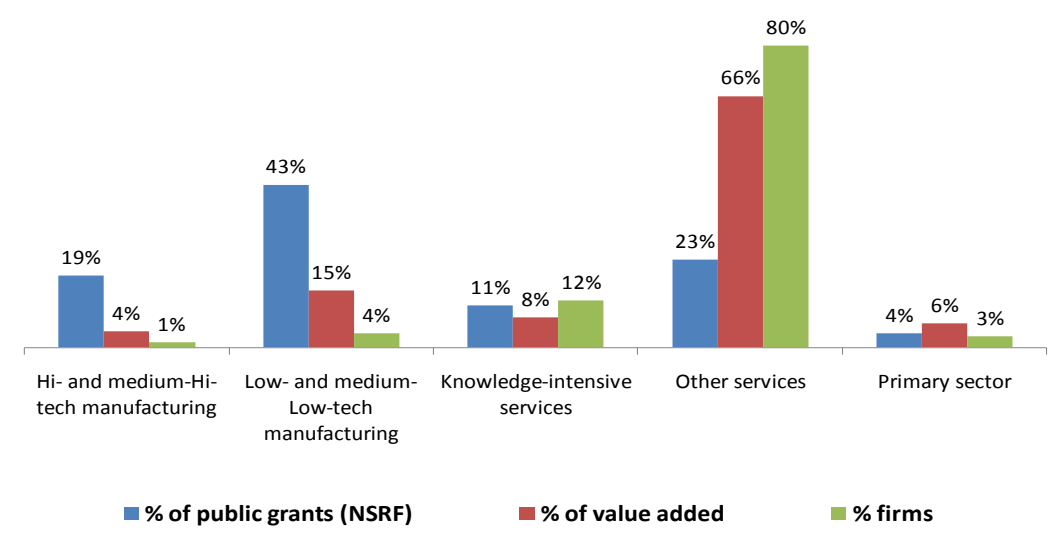

Source: NSRF Observatory. 
The incentives granted to non-knowledge intensive services focus heavily on tourism - an industry in which Portugal has an intermediate level of specialisation, and which is targeted by different national policy instruments.

\subsection{Mobi.E - Electric Mobility Network Program}

The three examples above refer to policy instruments that are apparently 'horizontal' in nature but the implementation of which reveals a preferred orientation for specific sectors. By contrast, the last case discussed here is a program that deliberately takes a sector specific focus from the outset.

The prospect of replacement of vehicles using petroleum products for electric vehicles has a huge potential - not only economic, but also political and environmental - especially for countries heavily dependent on imported oil and where electricity generation is done with little use of fossil fuels. A growing use of electric vehicles represent less need for oil imports, with beneficial effects on the trade balance, as well as in terms of security of energy supply. In addition, electric vehicles help to make better use of renewable energy by providing a storage form for the energy produced at night (when the level of energy consumption tends to be small). Finally, the large-scale diffusion of electric vehicles would significantly reduce $\mathrm{CO} 2$ emissions, contributing to meet the targets set by international rulings, as well as improving environmental quality. Electric vehicles are thus a powerful attraction for a country like Portugal - heavily dependent on imported fossil fuels, with worrying imbalances in the current account, and with an ambitious program of renewable energy. However, the generalisation of the electric vehicle as an alternative paradigm to the combustion engine faces several hurdles. In general, the persistent uncertainty about its economic viability discourages investment both on the part of producers and consumers. A major factor of uncertainty is the evolution of technology related to batteries - at present, the autonomy of an electric car does not reach two hundred miles, which puts the electric vehicle at a distinct disadvantage against a car moved by petrol or diesel.

Internationally there have been ad hoc solutions that aim to minimise this disadvantage. The best known case is the solution proposed by the Californian firm Better Place, which has begun to be implemented in Israel and Denmark. This is based on the principle of battery replacement, through a vast network of replacement stations. Notwithstanding the advantages of this system it ensures the desired autonomy of vehicles, and the initial investment is guaranteed by the private company - it contains a number of drawbacks, the most relevant of which is the huge initial investment required (which greatly reduces the prospects of competition in the market for battery replacements).

An alternative proposal was presented to the Portuguese government by Inteli - a semi-public think tank. The system proposed by Inteli is based on a network of charging stations, which 
ensures interoperability between the network of electrical mobility and the various brands and systems for charging batteries of electric vehicles - and with a higher content of domestic production.

Inteli promoted the formation of a consortium that included Novabase, EFACEC and EDP three leading national companies in IT services, electro-mechanics, and electricity, respectively - to develop what would become the Mobi.E project. This project consists of installing a network of electric charging stations distributed throughout the country, with global management system of energy flows and related financial transactions. This is essentially a nonproprietary system - it ensures the separation of ownership of charging stations, electricity distribution and energy supply services - and has as a distinctive feature the underlying business model for the management of energy and financial flows in the system. As in the management of ATM networks, Mobi.E's charging stations are all alike in the eyes of users, regardless of the operator who owns them. In particular, this system allows different companies to offer their commercial packages of energy supply - price lists, discount schemes, etc. - without consumers being forced to fill up at specific loading stations. This presupposes, in turn, the existence of a compensation system that distributes the revenues among the various players.

The Mobi.E consortium presented to the Portuguese Government a proposal to develop a pilot network of electric mobility across the country, consisting of the installation of 1350 regular and 50 fast charging stations, as well as developing the system for managing flows in the network. Funded initially by the Innovation Support Fund (IAF) - a public fund created as a counterpart for the granting of wind power licenses - the pilot network of Mobi.E is in operation since 2012.

For the companies involved in the consortium, this project was not only a source of revenue, but also an opportunity to develop and test pioneer products with a promising international demand. For the software companies involved - including Novabase and Critical Software - the electric mobility network presented great potential for the development of sophisticated IT systems (e.g., smart electrical network management interfaces, information networks, communication between the network, consumers and charging stations), which will probably be in high demand in the near future. For companies producing electronic equipment, the pilot project was an opportunity to develop solutions for charging stations that incorporate not only energy supply solutions but, more importantly, electronic systems for satellite communications. For EDP, the main Portuguese player in the electricity industry, Mobi.E is part of a learning process in the development of the business model to adopt in the future as a supplier of energy for electric vehicles.

The State's role in the development of the Portuguese Mobi.E was not limited to indirect financing (through the IAF). Its action was visible in the regulatory domain (classifying legal entities and the governance of the network, and setting the rules during the trial period - which, 
in practice, grant the consortium the monopoly of the process throughout 2011), but also the mobilisation of various levels of State administration for the paradigm of the electric vehicle. The latter involves measures such as the creation of tax incentives and subsidies for the purchase of electric cars, the renewal of public bodies' car fleets and the adoption of municipal regulations in favour of using electric vehicles in cities (e.g., preferential parking areas); promoting research networks linked to the theme, the creation of incentives for the involvement of national industry in developing solutions for charging batteries and construction of electric vehicles, the attraction of major manufacturers of electric vehicles and components, as well as the concerted action of the Portuguese economic diplomacy to promote the project Mobi.E. The growing visibility of the Portuguese electric mobility project has attracted international interest, opening business opportunities abroad to the companies involved in the project.

\section{CONDITIONS FOR AN EFFECTIVE AND LEGITIMATE INDUSTRIAL POLICY IN PORTUGAL}

As seen earlier, the critics of industrial policy point to the inability of the State apparatus to access the relevant information, as well as its vulnerability to capture by special interests, as factors that determine the undesirability of industrial policy. Indeed, while these risks are present in various forms of State intervention in the economy, the analysis of various historical examples suggest that criticism of industrial policy based on these risks should itself be critically assessed.

The idea of vulnerability of the State against private interests draws from a conception of human motivations according to which the interest of the individuals instrumental is the only guide to action. In this line of thought, there are no policy makers motivated by the promotion of the common good, nor State officials who take the public interest and professional pride as key references in the performance of their duties. According to this view, the performance of these individuals could only be consistent with the interest of the community they represent if it were possible to devise a system of compensations, penalties and controls that ensure the ongoing alignment of the common interest with the interests of its representatives. However, being virtually impossible to ensure the implementation of such a system, it is argued, public policy is always associated with the proliferation of corruption, cronyism and abuse of power.

This conclusion could not be more contrasting with the emphasis that is given by Evans (1995) and others to the characteristics of bureaucracy (in the Weberian sense of the term) in the conduct of successful industrial policies. Recurrently, those policies aimed at specific sectors of the productive sector that have proved more favourable to developing economies like South Korea, Taiwan and Brazil's were conducted by public agencies that were competent and loyal to 
the mission of the State. Notwithstanding the specificities of each context, policy options regarding the management of human resources in public administration (demanding recruitment policies, continuous training, remuneration and career prospects that are competitive with regard to the private sector, etc.) are systematically associated with examples in which the State apparatus has been effectively put to work in favour of structural change and economic development.

Regardless of the mechanisms that determine it, the commitment of those responsible for public agencies with the collective goals of economic development appears to be essential to overcome another problem that is emphasised by industrial policy's critics: the State's inability to access information that would be necessary to overcome market failures in the process of structural change.

Historically, in most situations in which the State intervened to promote specific activities, it did so in conjunction with private operators. Whether through a regulatory activity (aiming to encourage or inhibit certain behaviours), through subsidies to private investors, or even direct investment in State-owned enterprises, the success of public policy typically relies on mechanisms that foster the proximity between public agents and private actors, in order to elicit relevant information about the opportunities and constraints to development, as well as on the behaviours that the policy intends to influence (Rodrik, 2007).

In other words, although the State and the individuals who represent it should keep their autonomy with regard to private interests, their action is more effective when it takes advantage of the information and experience possessed by agents directly involved in the production. As Evans points out (1995), one of the factors that contributed to the success of industrial policy in East Asian countries was the ability to find institutional solutions that ensured an 'embedded autonomy' of public agencies over private economic actors - i.e. the ability of States to maintain a close relationship with the private sector, without being besieged by their interests.

Apart from human resource policies in public administration, such institutional solutions have as common traits: the clear identification of priorities for public intervention, focusing interventions in the most promising sectors; the political commitment at the highest level with the strategy of structural change; the assignment of clear mandates for public agencies, and their accountability based on results achieved; and the conditionality of support on achieving results (Rodrik, 2007).

These elements, as discussed above, are repeatedly mentioned as distinctive characteristics of the most successful processes of policy-led development experiences. Overall, they refer to the structure of the State's ability to formulate policies and assigning responsibilities for their implementation, ensuring the effectiveness and legitimacy of all public interventions.

However, it is worth noting that the relative importance of each of these elements may vary depending on the programs or public policy instruments in question. Indeed, taken individually, 
the forms of industrial policy entail different risks of State capture by private interests, as well as different possibilities for institutional solutions to minimise those risks.

The comparison between the four cases of industrial policy in Portugal referred to in the previous section - the tax benefits for investment of a contractual nature, the tax incentives for business $R \& D$, the direct incentives for business investment, and the electric mobility network program - help elucidate this idea. Such cases show significant differences in two dimensions: (i) the volume of private beneficiaries of public support (which is associated with a more or less recurrent nature of such support), and (ii) the dispersal of relevant skills among the public agencies that are responsible for policy design, implementation and monitoring. The following table compares the four types of intervention in the light of these dimensions.

\section{Number of private beneficiaries}

\begin{tabular}{|c|c|c|c|}
\hline \multirow{3}{*}{$\begin{array}{l}\text { Dispersion of relevant } \\
\text { skills in public } \\
\text { administration }\end{array}$} & & high & Low \\
\hline & High & $\begin{array}{l}\text { Direct incentives (grants and } \\
\text { loans) for business investment } \\
\text { (SI NSRF) }\end{array}$ & $\begin{array}{c}\text { Tax benefits for investment } \\
\text { of a contractual nature } \\
\text { (BFINC) }\end{array}$ \\
\hline & Low & $\begin{array}{l}\text { System of tax incentives for } \\
\text { business R\&D (SIFIDE) }\end{array}$ & $\begin{array}{l}\text { Electric mobility network } \\
\text { program (Mobi.E) }\end{array}$ \\
\hline
\end{tabular}

The direct incentive schemes for business investment (SI NSRF) and the system of tax incentives for business R\&D (SIFIDE) have in common the fact that they target a large number of companies. In the case of SI NSRF, between late 2007 and mid 2010, over three thousand companies have received public support for investment projects; in the case of SIFIDE, more than 600 companies received tax incentives in 2008 alone. While these figures represent a small percentage of the firms operating in the relevant period (reflecting a significant degree of selectivity of support), they contrast with the volume of companies supported under the investment tax benefits of a contractual nature (BFINC) - an annual average of about 12 companies between 1999 and 2008 - and with the program of electrical mobility (Mobi.E) (where the number of companies directly involved is reduced to a few tens).

The size of the set of enterprises receiving public support is not irrelevant to the risks of State capture by vested interests and to the possible institutional responses to those risks. On the one hand, a large number of recipients - and an even larger number of potential beneficiaries necessarily implies a greater scrutiny of public policies, particularly with regard to its efficiency, effectiveness and legitimacy. The beneficiary companies tend to question the procedures for allocation of support, and those companies to which support was denied tend to question the selection criteria and decision mechanisms. The public agencies and policy makers involved in the management of those policies are therefore more often exposed to public 
pressure, and they often respond to that pressure by making an effort to clarify the policy objectives and justify the institutional arrangements associated with policy implementation.

Additionally, the high number of beneficiaries appears typically associated with a higher recurrence of support. In fact, SI NSRF and SIFIDE are expected to be in place in a mediumterm horizon and are based on repeatable processes of project analysis and decision during this period, requiring significant dedicated human resources in the period of validity. The repetition of implementation procedures is conducive to institutional learning among the public agencies involved, strengthening the criteria and mechanisms for evaluating and selecting projects.

While both SI NSRF and SIFIDE target a broad spectrum of beneficiaries, the two instruments differ with respect to the distribution among public agencies of the skills that are relevant for policy implementation. Being a policy instrument co-financed by EU structural funds, the planning and management of SI NSRF necessarily involve the institutional structure provided for in the regulations of European cohesion policy - from the managing authorities of operational programs, to the fund coordinating and certification bodies, and auditing authorities. Additionally, since direct incentive schemes target various types of firms (industry, size, etc.) and projects, the capacity to examine the appropriateness and adequacy of applications is necessarily distributed among various public agencies that are not necessarily linked to the management and supervision of European structural funds. Moreover, the European funds - and in particular, the SI NSRF - constitute a significant source of funding for policies pursued by these national public agencies. This, together with the fact that they possess the relevant skills to implement SI NSRF, creates strong incentives for the relevant public agencies to get involved in the design and management of SI NSRF. This means that this policy instrument is subjected not only to a strong external scrutiny (due to the volume of beneficiaries, as discussed above) but also to processes of interaction and consultation involving various governmental bodies. By contrast, the number of institutional actors involved in SIFIDE is necessarily smaller, due to its specific domain (business $R \& D$ ) and the fact it is unrelated to European funds.

The dispersion of skills relevant to the implementation of public policies is also present, albeit to a lesser extent, in the case of tax benefits for investment of a contractual nature (BFINC). As discussed above, this policy instrument is deployed in complex negotiations with large investors (often foreign), covering areas as vast as taxation, international trade, licensing, training, R\&D, among others. Typically, different public agencies are called to comment on specific aspects of investment contracts negotiated for BFINC, introducing some elements of scrutiny within the public administration. However, in contrast to the SI NSRF, not only the diversity of public agencies involved is more limited (it often excludes, for example, entities related to the management, control and audit of European structural funds), as its intervention is of sporadic nature, limiting the potential for inter-institutional learning and scrutiny. 
Finally, in the case of Mobi.E, as seen above, the number of both private beneficiaries and public agencies involved is limited. As a result, it tends to be subject to scrutiny both within and outside the State apparatus.

In short, the differences between various forms of industrial policy - as regards the dispersion of relevant skills in public administration and the number of beneficiaries - carry different risks of State capture by special interests, which are inversely proportional to the internal and public scrutiny they are subject to in a democratic society. Such differences are also associated with different institutional solutions for minimising the risks of different State capture by private interests, as suggested in the following table.

\section{Institutional solutions for reducing the risks of State capture by special interests}

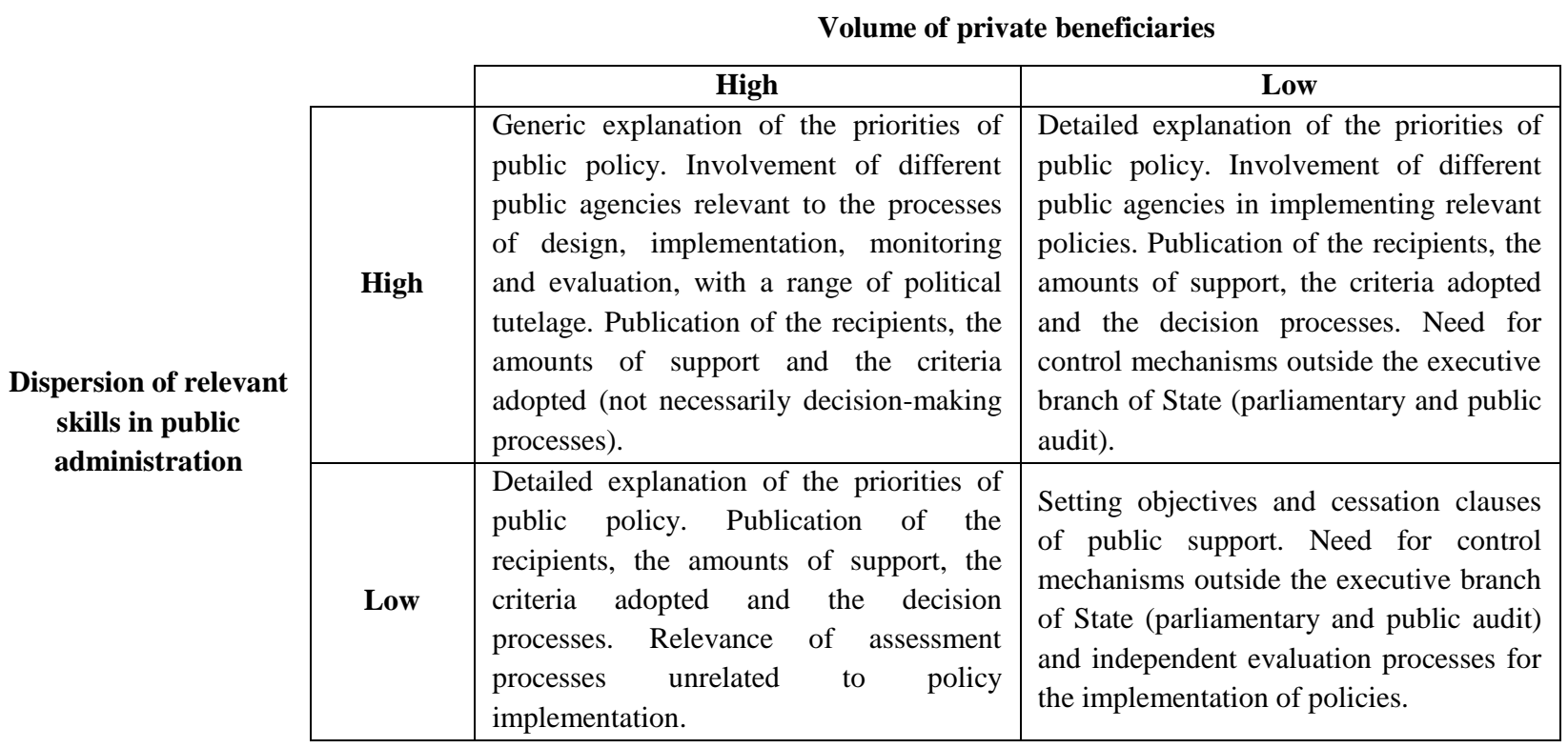




\section{CONCLUSIONS}

State intervention in support of specific productive activities - or, in other words, industrial policy - was, for many decades, a controversial topic in both academic and political debates. Advocates argued for the need to address market failures that prevent the structural changes that are necessary for economic development, whereas detractors of industrial policy held pessimistic views about the capacity of public agencies to intervene effectively, without being captured by special interests. The confrontation of theoretical arguments has not been resolved by empirical research, neither the more qualitative and institutional studies (the results of which can hardly be generalised), nor the econometric and statistical exercises (which face arguably insurmountable methodological hurdles).

Given the uncertainty of the debate about the usefulness of industrial policy (and noting the fact that this type of intervention has been present in the policies of most industrialised countries until the present time) the discussion of State intervention in support of specific activities has been experiencing a change of focus in recent years - falling away from the rationale of industrial policies to focus on the political and institutional conditions that promote the effectiveness and legitimacy of the policies pursued.

Based on historical analysis of a set of successful (and less successful) cases in which the State has played an active role in supporting structural change, several factors have been identified that promote the effectiveness and legitimacy of industrial policies, such as: human resource management practices in public administration that promote the quality of interventions and the autonomy of civil servants; identifying clear priorities for public intervention, focusing interventions on the most promising activities; the political commitment at the highest level with the strategy of promoting structural change; the allocation of clear mandates to the public agencies involved and their accountability based on performance; or the conditionality of support for achieving results (Rodrik, 2007).

These factors tend to be presented in the literature in a general way, identifying the least common denominator of successful cases of industrial policies. In this paper we analyse in greater detail the conditions for effective and legitimate industrial policies, examining four cases of public interventions in Portugal. Our analysis emphasises the differences between the various interventions according to two dimensions: the number of (potential) beneficiaries targeted by the policy and the diversity of public agencies in possession of relevant skills for managing the interventions. These factors help to determine the level of scrutiny to which public policies are subjected, either by private actors or within the State apparatus. Both sources of scrutiny help to minimise the risks of capture of public resources by private interests, and to foster institutional learning processes that promote the effectiveness of policies. 
Overall, the analysis developed here suggests that: (i) where the nature of the policies favours internal or external scrutiny, the effectiveness and legitimacy of industrial policy can benefit from pursuing such possibilities of enhancing scrutiny, (ii) when the interventions are, by their nature, little exposed to scrutiny by the beneficiaries or by different public agencies, alternative mechanisms for monitoring, independent audits and policy evaluations should be mobilised in order to minimise risks of capture of public resources by private interests and encourage learning processes leading to more effective interventions. 


\section{REFERENCES}

Amsden, A. (1989). Asia's Next Giant: Late Industrialization in Korea. New York: Oxford University Press.

Augusto Mateus \& Associados (2005). Relatório Final da Actualização da Avaliação Intercalar do Programa de Incentivos à Modernização da Economia. Lisboa.

Block, F. (2008). "Swimming Against the Current: The Rise of the Hidden Developmental State in the United States." Politics \& Society 36 (2), pp. 169-206.

Chandra, V. (2010). Technology, adaptation, and exports. How some Developing Countries Got It Right. Washington: The World Bank.

Chang, H.-J. (2006). Bad Samaritans: Rich Nations, Poor Policies and the Threat to the Developing World. London: Random House.

Comissão Certificadora para os Incentivos Fiscais à I\&D Empresarial (2010). SIFIDE - Sistema de Incentivos Fiscais à I\&D Empresarial: 2006 - 2008. Lisboa: FCT, GPEARI-MCES e AdI.

CTC/QREN - Comissão Técnica de Coordenação do Quadro de Referência Estratégico Nacional (2010). Relatório Anual do QREN II. Lisboa, Observatório do QREN.

Evans, P. (1995). Embedded Autonomy: States and Industrial Transformation. Princeton: Princeton University Press.

IMF (2008). "France, Greece, Italy, Portugal and Spain - Competitiveness in the Southern Euro Area". IMF Country Report No. 08/145.

Kaldor, N. (1966). Causes of the Slow Rate of Growth of the United Kingdom. Cambridge: Cambridge University Press.

Krueger. A. (1974). "The Political Economy of the Rent-Seeking Society." American Economic Review 64 (3), pp. 291-303.

Lewis, W. A. (1954). "Economic Development with Unlimited Supplies of Labor", Manchester School of Economic and Social Studies 22, pp. 139-91.

OECD (2007). Economic Survey of the European Union. Paris: OECD.

Olson, M. (1971). The Logic of Collective Action: Public Goods and the Theory of Groups. Cambridge, Massachusetts : Harvard University Press. 
Institutional conditions for effective and legitimate industrial policies: the case of Portugal

Pack, H.; Saggi, K. (2006). "Is There a Case for Industrial Policy? A Critical Survey," The World Bank Research Observer 21(2), pp. 267-297.

Pasinetti, L. (1981). Structural Change and Economic Growth. Cambridge: Cambridge University Press.

Rodrik, D. (2007). One Economics, Many Recipes: Globalization, Institutions, and Economic Growth. Princeton: Princeton University Press.

Rodrik, D. (2008). "Normalizing Industrial Policy." Commission on Growth and Development Working Paper n.3. Washington: The World Bank.

Shapiro, H. (2007), "Industrial Policy and Growth". In J.A. Ocampo (2007), Growth Divergences. Explaining differences in economic performance. Londres: Zed Books.

Thirwall, A. P. (1979). "The Balance of Payments constraint as an explanation of international growth differences", Banca Nazionale del Lavoro Quarterly Review 3, pp. 245-253.

Tribunal de Contas (2009). Relatório de Auditoria aos Benefícios Fiscais ao Investimento de Natureza Contratual. Relatório de Auditoria no 43/2009 - 2ª Secção.

Wade, R. (2003). Governing the Market: Economic Theory and the Role of Government in East Asian Industrialization. Princeton: Princeton University Press.

World Bank (1993). The East Asian Miracle: Economic Growth and Public Policy . Oxford: Oxford University Press. 